[Original]

\title{
Development of a Dehumidification System for a Passive Sampler for Determining 1,3-Butadiene
}

\author{
Kenji Sakurai, Yuichi Miyake and Takashi Amagai* \\ Graduate School of Nutritional and Environmental Science, University of Shizuoka, Suruga-ku, Shizuoka 422-8526, \\ Japan
}

\begin{abstract}
The passive sampler is a simple device for collecting gaseous compounds. It is affected by environmental conditions such as relative humidity, but a dehumidification system (DHS) has not been developed for it. We have developed a dehumidification device for the passive sampler for determining 1,3-butadiene. It consists of a passive sampler surrounded by a DHS consisting of a basket filled with granular magnesium perchlorate as the dehumidification agent. The passive sampler consists of a porous polytetrafluoroethylene tube packed with Carboxen 1000 adsorbent. We compared the amounts of water adsorbed on the Carboxen 1000 adsorbent in the presence and in the absence of the DHS; the results showed that the DHS prevented water from entering the sampler. Volatile organic compounds that entered the sampler were collected by the Carboxen 1000 adsorbent. In the case of 1,3-butadiene, much higher amounts were collected by the passive sampler with the DHS than without it. This may be due to interference of adsorption or acceleration of 1,3-butadiene degradation by the water-soluble oxidant on the surface of the Carboxen 1000 adsorbent.
\end{abstract}

Keywords : passive sampler, dehumidification system, 1,3-butadiene, volatile organic compounds.

(Received June 6, 2016, accepted August 12, 2016)

\section{Introduction}

1,3-Butadiene is a highly reactive and toxic air pollutant that has been detected in air along roadsides and in urban areas [1]. Sources of 1,3-butadiene include motor vehicle exhaust, chemical manufacturing plants, plastic and rubber factories, and oil refineries. The effect of 1,3-butadiene on human health is a topic of great concern. The International Agency for Research on Cancer has classified 1,3-butadiene as a probable human carcinogen [2].

Methods for measuring the concentration of 1,3-butadiene have been reported previously [3-6]. Passive sampling is a simple, reliable technique for determin- ing indoor and outdoor pollutants, their spatial distribution, and the level of personal exposure to volatile organic compounds (VOCs) [7-10], but it is affected by environmental conditions such as temperature, relative humidity, and wind speed, and minimizing the effects of these conditions during sampling is important. Relative humidity is an important environmental factor during sampling of gaseous compounds, especially for carbonaceous adsorbents $[11,12]$. On the Pacific Ocean side of Japan, it is hot and very humid in the summer, and dew and frost form during the winter. Samplers with carbonaceous adsorbents easily absorb moisture in such climates. During previous passivesampling campaigns, we found significant amounts

*Corresponding Author: Takashi AmAgAI, Graduate School of Nutritional and Environmental Science, University of Shizuoka, 52-1 Yada, Suruga-ku, Shizuoka 422-8526, Japan. Tel \& Fax: +81-54-264-5798, E-mail: amagai@u-shizuoka-ken.ac.jp 
of water in the adsorbents after sampling. Several researchers have evaluated the effect of relative humidity on the rate of uptake of VOCs by carbonaceous adsorbents. For example, Martin et al. reported that $\mathrm{C}_{4}-\mathrm{C}_{13}$ VOCs were collected by carbonaceous adsorbents with few problems at high humidity [4]. Lan and Binh reported that the effect of relative humidity on the rate of uptake of benzene and its derivatives on activated charcoal was negligible [13]. Seethapathy and Górecki collected $n$-alkanes and aromatic hydrocarbons by a permeation passive sampler at three humidity levels and concluded that the uptake rates were unaffected by the humidity level [14]. In contrast, Roukos et al. reported that relative humidity negatively affected the rates of uptake of benzene and toluene on graphite carbon black [15]. Kawamoto and Sakaji reported that the uptake rate of tetrachloroethylene by activated charcoal decreased when the relative humidity exceeded $80 \%$, and that this decrease was due to a decrease in the adsorption capacity of the adsorbent [16]. They reported that the uptake rate of tetrachloroethylene was relatively constant when the relative humidity was below $80 \%$. Thus, high humidity affected the sampling of VOCs by the passive sampler in some reports, but a dehumidification system (DHS) has not been developed for passive samplers.

We have developed a DHS for passive samplers. We used magnesium perchlorate as a dehumidifying agent; magnesium perchlorate is often used in active samplers to remove moisture from the air during sampling. The magnesium perchlorate was placed in a basket around the passive sampler, and the performance of the DHS was evaluated.

\section{Methods and Materials}

Magnesium perchlorate (8-24 mesh), $o$-xylene, and a standard solution of 1,3-butadiene dissolved in toluene (40 wt \%) were purchased from Wako Pure Chemical Industries Ltd. (Osaka, Japan). Carboxen 1000, a spherical carbon molecular sieve, was obtained from Sigma-Aldrich, Inc. (St. Louis, MO, USA).

The passive sampler consisted of a $5.0 \mathrm{~cm}$ long $\times 0.7$ $\mathrm{cm}$ diameter porous polytetrafluoroethylene tube (Sibata Scientific Technology, Tokyo, Japan) packed with either granular activated charcoal or Carboxen 1000
[17]. The sampler was fixed in the center of either a standard $(5.0 \mathrm{~cm}$ long $\times 3 \mathrm{~cm}$ diameter) or small $(5.0$ $\mathrm{cm}$ long $\times 2 \mathrm{~cm}$ diameter) cylindrical basket, and the basket was filled with magnesium perchlorate, the dehumidification agent. A protective cup made of a paper cup shielded the system from wind and rain (Fig. 1).

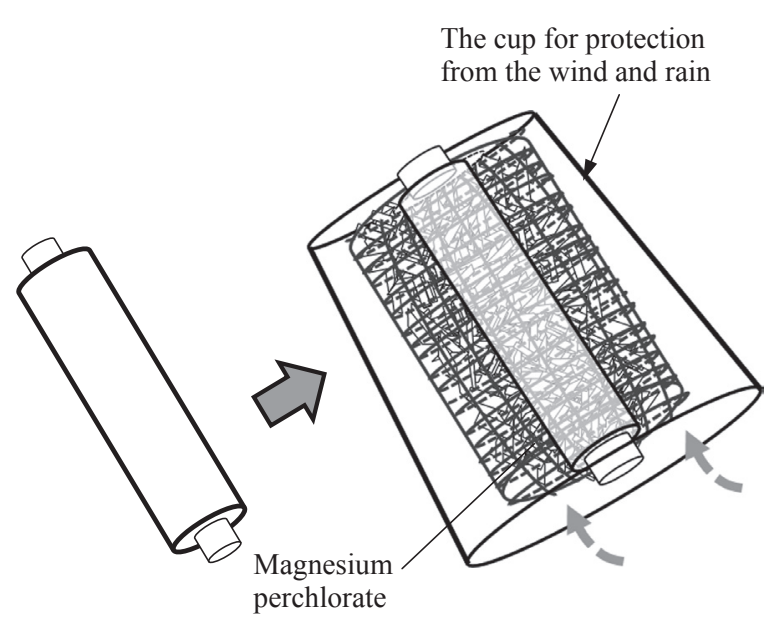

Fig. 1. Diagram of the passive-sampler with a dehumidification system (DHS).

Sampling started when the passive sampler was exposed to the air. The sampler was quickly set in the basket, which was filled with magnesium perchlorate and then set in the protective cup.

Sampling was conducted from July to August 2011 in Gotenba City, Shizuoka, Japan. Shizuoka Prefecture faces the Pacific Ocean. Gotenba City (latitude $35^{\circ} 19^{\prime} \mathrm{N}$, longitude $138^{\circ} 56^{\prime} \mathrm{E}$ ) is a typical Japanese commercial city, with a temperate climate (average temperature $25.3^{\circ} \mathrm{C}$ ) and 88,896 inhabitants (June 2012). We measured the concentration of 1,3-butadiene at the side of a heavily traveled ( $>200$ vehicles per hour) trunk road there.

Desorption from the sampling tube and precondensation of the 1,3-butadiene were carried out with an automated thermal Turbomatrix 650ATD desorber (Perkin-Elmer, Norwalk, CT, USA). After sampling, the Carboxen 1000 in the sampling tube was transferred to a stainless steel desorption cartridge ( $89 \mathrm{~mm}$ $\times 4.5 \mathrm{~mm}$ inside diameter (i.d.)). The 1,3-butadiene was desorbed under a $20 \mathrm{ml} / \mathrm{min}$ helium flow at $280^{\circ} \mathrm{C}$ 
for $15 \mathrm{~min}$ and then cryofocused on a Carboxen trap at $5^{\circ} \mathrm{C}$. This trap was heated to $350^{\circ} \mathrm{C}$ at $40^{\circ} \mathrm{C} / \mathrm{s}$ and then held at $350^{\circ} \mathrm{C}$ for $4 \mathrm{~min}$. The desorbed 1,3-butadiene was transferred to a gas chromatograph (GC) column through a methylpolysiloxane line heated at $350^{\circ} \mathrm{C}$. The inlet and outlet split flows were $3 \mathrm{~m} / / \mathrm{min}$.

The gas chromatograph with mass spectrometer (GC/MS) system consisted of a GC6890 gas chromatograph coupled with a 5975C mass-selective detector (Agilent Technologies International Japan, Ltd., Hachioji, Japan). A (5\%-phenyl) methylpolysiloxane column (DB-5, $60 \mathrm{~m}$ length $\times 0.32 \mathrm{~mm}$ i.d., $0.25 \mu \mathrm{m}$ film thickness, Agilent) was used for separation. The column oven temperature program was as follows: increase from 35 to $80^{\circ} \mathrm{C}$ at $5^{\circ} \mathrm{C} / \mathrm{min}$ over $9 \mathrm{~min}$, hold for $2 \mathrm{~min}$ at $80^{\circ} \mathrm{C}$, increase to $250^{\circ} \mathrm{C}$ at $20^{\circ} \mathrm{C} / \mathrm{min}$ over $8.5 \mathrm{~min}$, hold at $250^{\circ} \mathrm{C}$ for $10.5 \mathrm{~min}$. The carrier gas helium (flow rate, $1.0 \mathrm{ml} / \mathrm{min}$ ). Mass spectra were recorded in the electron impact mode at $70 \mathrm{eV}$, scanning the $m / z 29-250$ range. The interface and source temperatures were 150 and $250^{\circ} \mathrm{C}$, respectively. The MSD Productivity ChemStation software (Agilent) was used for data acquisition and data processing.

We verified that the concentration of the 1,3-butadiene in the sample blanks was below the limit of detection (detection limit defined at 3 times the standard deviation of the lowest concentration of the standard solution). A field blank sample was taken on each sampling day, and the concentrations of 1,3-butadiene in the blank samples were below $0.01 \mu \mathrm{g} / \mathrm{m}^{3}$. The sample recovery ratios ranged from $94 \%$ to $99 \%$, and relative errors were small, validating our procedure.

We have previously described the method for converting from the amount of 1,3-butadiene collected by a passive sampler to its air concentration [6]. The method involves simultaneous sampling with active and passive samplers in a chamber and determining a conversion equation from the results. The sampling rate (SR) of 1,3-butadiene by a passive sampler is calculated as

$$
S R=\frac{m}{c t}
$$

where $m$ is the amount $(\mu \mathrm{g})$ collected by the passive sampler during an exposure time $t(\mathrm{~min})$ at a concentration in air $c\left(\mu \mathrm{g} / \mathrm{m}^{3}\right)$. An SR value of $(24.3 \pm 0.5)$ $\times 10^{-6}\left(\mathrm{~m}^{3} / \mathrm{min}\right)$ was calculated from the experiments, then an SR value of $24.3 \times 10^{-6}\left(\mathrm{~m}^{3} / \mathrm{min}\right)$ was used in this study.

We simultaneously sampled air in Gotenba City with passive samplers with and without the humidification system to compare the results. Samplers were placed at the side of a road with a traffic volume of about 100 vehicles per hour. Samples were collected for $24 \mathrm{~h}\left(20^{-}-35^{\circ} \mathrm{C}\right.$, relative humidity $\left.<95 \%\right)$ under sunny, cloudy, and rainy conditions.

\section{Results and Discussion}

\section{Evaluation of the performance of the DHS}

It is humid in the summer on the Pacific Ocean side of Japan, and dew forms during the winter. Therefore, carbon adsorbents such as activated carbon and Carboxen 1000 easily adsorb water vapor during these seasons. To test the performance of our DHS, we placed passive samplers with and without DHS outdoors for $24 \mathrm{~h}$ in the wet season. The weights of the samplers were measured before and after exposure (Fig. 2).

Without the DHS, the weight of the passive sampler increased by $0.060 \pm 0.003 \mathrm{~g}$. This increase in weight was attributed to adsorbed water (after sampling, the adsorbent was put into a test tube containing carbon

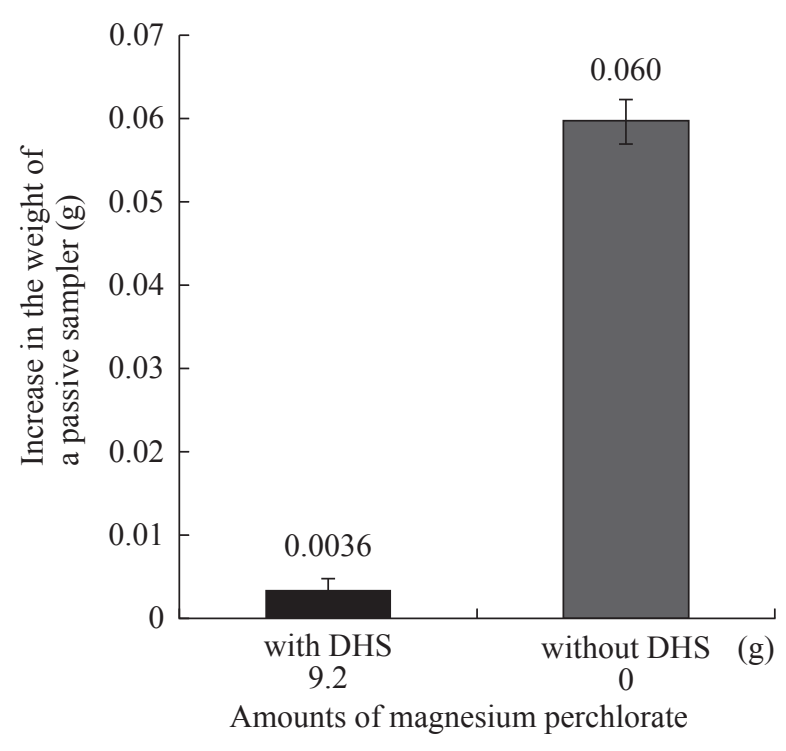

Fig. 2. The performance of the DHS. Increase in the weight of a passive sampler with or without the DHS placed outdoors for $24 \mathrm{~h}$ during the rainy season was measured $(n=4)$. 
disulfide, and the water was separated). In contrast, with the DHS, the weight gained by the sampler was negligible. These results showed that the DHS was effective.

We tested whether the DHS prevented adsorption of 1,3-butadiene. It was collected indoors at low relative humidity $(40 \%)$ with passive samplers with and without the DHS. The DHS did not interfere with the adsorption of 1,3-butadiene (Fig. 3).

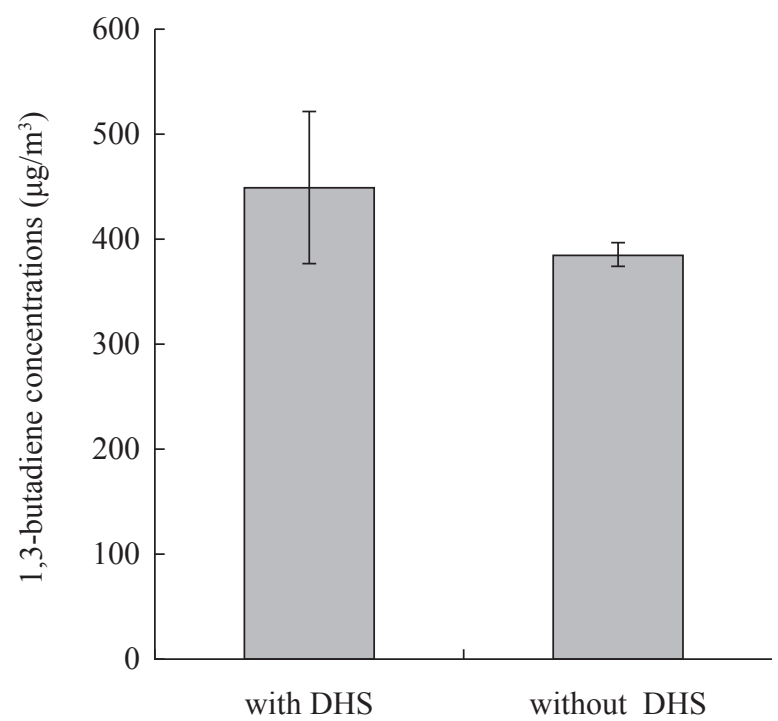

Fig. 3. Comparison of 1,3-butadiene collection amounts with the DHS. 1,3-butadiene concentrations were determined with passive samplers with and without the DHS in the chamber $(n=2)$.
Comparison of 1,3-butadiene concentrations with and without the DHS

Next we determined the roadside 1,3-butadiene concentrations with passive samplers with and without the DHS during July-August (dew typically forms during this season). Fig. 4 shows the results. Because the sampling was performed outdoors, temperature, relative humidity, and wind speed varied significantly during sampling (see Fig. 4 for weather conditions and relative humidity on the sampling days).

The results in Fig. 4 show that the 1,3-butadiene concentrations determined with the passive sampler with the DHS were higher than those without it and were independent of the weather and relative humidity. For the sampling on July $14-15$, the amount of 1,3-butadiene collected by the passive sampler with the DHS was 1.3 times as high as that without it. The weather on August 10-11 and August 14-15 was cloudy, and the relative humidity ranged from $68 \%$ to $86 \%$. The amounts of 1,3-butadiene collected by the passive sampler with the DHS were 2.5 times as high as those without it on these days. Without the DHS, the collection of 1,3-butadiene by the adsorbent would have been hampered if the surface of the adsorbent had been covered with a substantial amount of moisture. Moreover, exhaust gases from vehicles contain a variety of compounds such as oxidants that could degradate 1,3-butadiene. Thus, the surface of the adsorbent

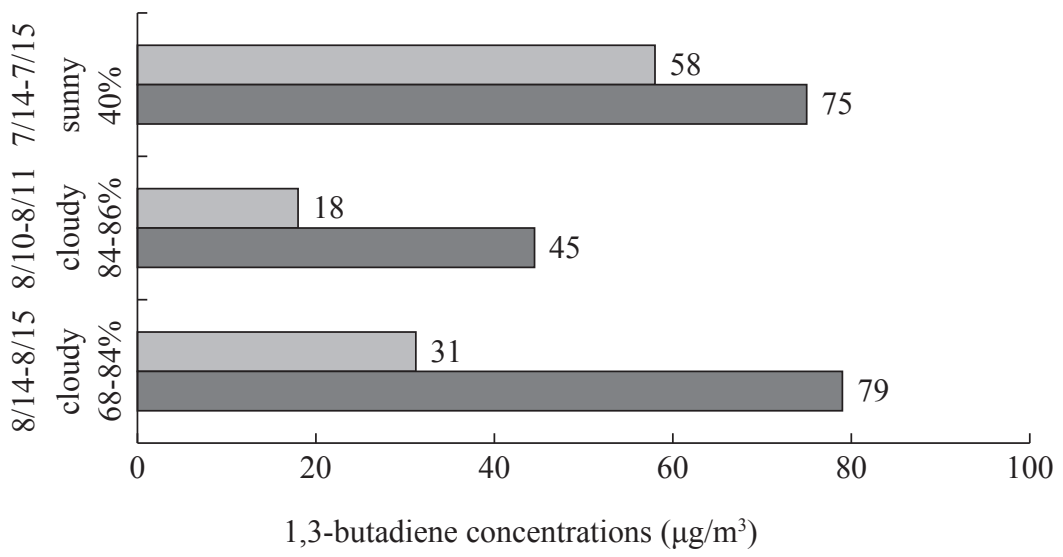

Fig. 4. Comparison of 1,3-butadiene concentrations with the DHS. The roadside 1,3-butadiene concentrations were determined with passive samplers with and without the DHS. $\square$ : passive-sampler without the DHS, $\square$ : passive-sampler with the DHS. 
was covered with moisture, and sampling was influenced by the potentially interfering compounds in the vehicle exhaust.

\section{Effects of wind speed on the DHS}

Several researchers have reported that wind speed significantly affects sampling rate: higher wind speeds lead to higher sampling rates $[8,18-20]$. Because the DHS perturbs wind flow, the amount of VOCs collected by a passive sampler equipped with the DHS should decrease. Contrary to this expectation, we found that the amount of 1,3-butadiene collected with the passive sampler with the DHS increased in the presence of wind. To investigate further, we collected xylene (a stable VOC typically found in the exhaust of motor vehicles) with samplers with and without the DHS and compared the results.

Figure 5 shows that the amounts of collected xylene by the passive sampler with and without the DHS. The results were compared by $t$-test, and we found the collection amounts of xylene decreased significantly when the DHS was used. This result was consistent with the literature. The wind speed at the surface of the passive sampler without the DHS was expected to be faster

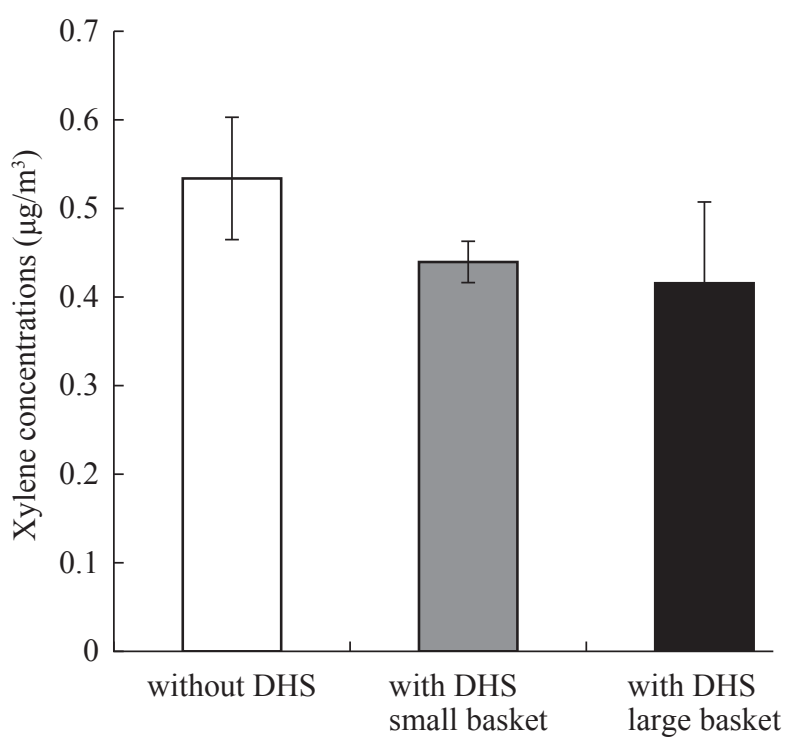

Fig. 5. Xylene concentrations in samples collected outdoors with passive samplers with and without the DHS $(n=6)$. Samplers with the DHS contained either a small basket or a standard basket filled with magnesium perchlorate. than that with the DHS. The sampler without the DHS should have collected much more 1,3-butadiene than the sampler with the DHS. The latter, however, collected more 1,3-butadiene, as shown in Fig. 4. Without the DHS, not only 1,3-butadiene but also water-soluble oxidants may adsorb on the activated charcoal in the passive sampler, and these oxidants may degrade the 1,3-butadiene. We will detect the degradation products in further research.

\section{Conclusion}

We have developed a device for indoor and outdoor passive sampling of VOCs in air. The device consists of a passive sampler surrounded by a DHS consisting of a basket filled with magnesium perchlorate. The performance of the DHS in preventing moisture from entering the sampler is excellent. An indoor chamber experiment showed that, in the case of 1,3-butadiene, the DHS did not decrease the ability of the sampler to collect VOCs. Much higher amounts of 1,3-butadiene were collected with the DHS than without it. The rate of collection of 1,3-butadiene by the device increased with slight increases in wind speed, contrary to expectation. This result may indicate that the device prevented 1,3-butadiene from degrading.

\section{Conflicts of Interest}

The authors declare no conflict of interest associated with this manuscript. Dr.Amagai report grants from Sibata Science and Technology, during the conduct of the study; grants from Ministry of Health, Labour and Welfare, grants from Smoking Research Foundation.

\section{References}

1. World Health Organization (2001): 1,3-butadiene: human health aspects. Hughes K \& International Programme on Chemical Safety. WHO Geneva. http:// www.who.int/ipcs/en/ (accessed on Aug.01.2016)

2. International Agency for Research on Cancer (1999): Re-evaluation of some organic chemicals, hydrazine and hydrogen peroxide (Part one). IARC monographs on the evaluation of carcinogenic risks to humans 71 . IARC Lyon pp 45-183 
3. NIOSH (1994): 1,3-butadiene, NIOSH manual of analytical methods. Fourth ed. Method 1024. National Institute for Occupational Safety and Health, USA https://www.cdc.gov/niosh/docs/2003-154/ (accessed on Aug.01.2016)

4. Martin NA, Duckworth P, Henderson MH, Swann NRW, Granshaw ST, Lipscombe RP \& Goody BA (2005): Measurements of environmental 1,3-butadiene with pumped and diffusive samplers using the sorbent Carbopack X. Atmos Environ 39: 1069-1077

5. Strandberg B, Sunesson AL, Sundgren M, Levin JO, Sallsten G \& Barregard L (2006): Field evaluation of two diffusive samplers and two adsorbent media to determine 1,3-butadiene and benzene levels in air. Atmos Environ 40: 7686-7695

6. Sakurai K, Miyake Y \& Amagai T (2013): Reliable passive-sampling method for determining outdoor 1,3-butadiene concentrations in air. Atmos Environ 80: 198-203

7. Crump D (1999): Application of diffusive samplers. In Organic Indoor Air Pollutants. Wiley-VCH Verlag GmbH. D-69469 Weinheim pp 57-71

8. Seethapathy S, Górecki T \& Li X (2008): Passive sampling in environmental analysis. J Chromatogr A 1184: 234-253

9. Amagai T (2011): Measurement of anthropogenic VOCs and their impact on environment. Environ Natural Resource J 9(1): 1-5

10. Koblizkova M, Genualdi S, Lee SC \& Harner T (2012): Application of sorbent impregnated polyurethane foam (SIP) disk passive air samplers for investigating organochlorine pesticides and polybrominated diphenyl ethers at the global scale. Environ Sci Technol 46: 391-396

11. Gawrys M, Fastyn P, Gawlowski J, Gierczak T \& Niedzielski J (2001): Prevention of water vapour adsorption by carbon molecular sieves in sampling humid gases. J Chromatogr A 933: 107-116
12. Fastyn P, Kornacki W, Gierczak T, Gawłowski J \& Niedzielski J (2005): Adsorption of water vapour from humid air by selected carbon adsorbents. J Chromatogr A 1078(1-2): 7-12

13. Lan TTN \& Binh NTT (2012): Daily roadside BTEX concentrations in East Asia measured by the Lanwatsu, Radiello and Ultra I SKS passive samplers. Sci Total Environ 441: 248-257

14. Seethapathy S \& Górecki T (2010): Polydimethylsiloxane-based permeation passive air sampler. Part II: Effect of temperature and humidity on the calibration constants. J Chromatogr A 1217: 7907-7913

15. Roukos J, Locoge N, Sacco P \& Plaisance H (2011): Radial diffusive samplers for determination of 8-h concentration of BTEX, acetone, ethanol and ozone in ambient air during a sea breeze event. Atmos Environ 45: 755-763

16. Kawamoto K \& Sakaji N (1995): Performance evaluation of passive samplers for the measurement of VOC in air. J Environ Chem 5: 450-451 (in Japanese)

17. Gallego E, Rocaa FJ, Peralesa JF \& Guardino X (2011): Comparative study of the adsorption performance of an active multi-sorbent bed tube (Carbotrap, Carbopack X, Carboxen 569) and a Radiello diffusive sampler for the analysis of VOCs. Talanta 85: 662-672

18. Plaisance H, Piechocki-Minguy A, Gracia-Fouque S \& Galloo JC (2004): Influence of meteorological factors on the $\mathrm{NO}_{2}$ measurements by passive diffusion tube. Atmos Environ 38:573-580

19. Tuduri L, Harner T \& Hung H (2006): Polyurethane foam (PUF) disks passive air samplers: Wind effect on sampling rates. Environ Pollut 144: 377-383

20. Guo H, Lin H, Zhang W, Deng C, Wang H, Zhang Q, Shen Y \& Wang X (2014): Influence of meteorological factors on the atmospheric mercury measurement by a novel passive sampler. Atmos Environ 97: 310-315 
1,3-ブタジエン捕集用パッシブサンプラーの除湿装置の開発

櫻井 健治, 三宅 祐一, 雨谷 敬史

静岡県立大学大学院 薬食生命科学総合学府 環境科学専攻

要旨：捕集時にポンプを使用しないパッシブサンプラーは, 置いておくだけの分子拡散を利用してガス状污 染物質を捕集する装置であり, 操作が簡便で電源が要らないなど有用な手法である。しかし, 湿度, 風などの環境条 件の影響を受けるという報告があり問題となっているので, 本研究では, 世界で初めてパッシブサンプラー用の除 湿装置を考案し, その性能を1,3-ブタジエンの捕集で検討した。 1,3-ブタジエンは, 自動車排出ガスに多く含まれ, また健康影響も大きい大気污染物質であるが, 分解しやすく, その捕集精度が問題となっている化合物である．除 湿装置は, ステンレス製のかごに, 過塩素酸マグネシウムを充填したもので, 過塩素酸マグネシウムはアクティブサ ンプラー用の除湿剤として既に使用されている除湿剤である。この結果, 除湿装置をつけたパッシブサンプラーで は, パッシブサンプラー単独の場合と比較して 1.3〜2.5 倍の捕集量を得ることが分かった. 1,3-ブタジエン以外の化 合物, 例えばキシレンでは, 除湿装置が風防装置の役割を果たしたため, 捕集量が逆に減少した。これらのことから, 1,3-ブタジエンの場合, 除湿装置が酸化性の物質も同時に防ぐ可能性が示された.

キーワード : パッシブサンプラー, 除湿装置, 1,3-ブタジエン, 揮発性有機化合物.

J UOEH(産業医大誌) 38(3)：215 - 221 (2016) 